THE LONGEST NIGHT 
The University of California Press gratefully acknowledges the generous support of the Floersheimer Center for Constitutional Democracy at the Benjamin N. Cardozo School of Law. 


\title{
THE LONGEST NIGHT
}

Polemics and Perspectives on Election 2000

\author{
EDITED BY \\ Arthur J. Jacobson and \\ Michel Rosenfeld
}

UNIVERSITY OF CALIFORNIA PRESS

Berkeley Los Angeles London 
University of California Press

Berkeley and Los Angeles, California

University of California Press, Ltd.

London, England

(C) 2002 by the Regents of the University of California

The editors gratefully acknowledge the following publications: London Review of Books, vol. 23, no. 3, for Bruce Ackerman, "Anatomy of a Constitutional Coup"; The Green Bag, Inc., Copyright 2001, for Robert W. Bennett, "Popular Election of the President without a Constitutional Amendment"; and New York Review of Books, vol. 48, no. 1, for Ronald Dworkin, "A Badly Flawed Election," and vol. 48, no. 3, for Charles Fried, "A Badly Flawed Election: An Exchange" and "Reply by Ronald Dworkin."

Library of Congress Cataloging-in-Publication Data

The longest night : polemics and perspectives on election $2000 /$ edited by Arthur J. Jacobson and Michel Rosenfeld.

p. $\mathrm{cm}$.

Includes bibliographical references and index.

ISBN o-520-23373-5 (cloth : alk. paper) - ISBN o-520-23549-5 (paper : alk. paper)

1. Presidents-United States-Election-200o. 2. Election lawUnited States. I. Jacobson, Arthur J. II. Rosenfeld, Michel, 1948$\mathrm{JK}_{5} 262002$

324.973'o929-dc2 1

$200100775^{8}$

CIP

Manufactured in the United States of America

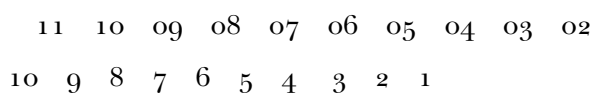

The paper used in this publication is both acid-free and totally chlorine-free (TCF). It meets the minimum requirements of ANSI/

NISO Z39.48-1992 (R 1997) (Permanence of Paper).ळ 
For our children, Sam and Ben Jacobson and Maia and Alexis Rosenfeld, to whom we entrust the future of our democracy 
This page intentionally left blank 